\title{
PRINCIPLES OF SUSTAINABLE ARCHITECTURE DESIGN IN CROWDED RESIDENTIAL COMPLEXES WITH AN OUTLOOK TO RESUSCITATION OF NATURE IN ARCHITECTURE
}

\author{
Kiana Mohammadi \\ M.Sc.Architecture,Department of Architecture, Central Tehran Branch Faculty, Islamic Azad University, \\ Tehran, Iran \\ Hooman Sobouti \\ Assistant Professor, Department of Architecture, Zanjan Branch, Islamic AzaUniversity, Zanjan, Iran and \\ Young Researchers and Elite Club, Zanjan Branch, Islamic Azad University, Zanjan, Iran
}

\begin{abstract}
Issue of sustainable development has been introduced as one of the most common and important issues throughout the world, turned to an important issue in all the specialized fields and encompassed economic, social, cultural and other aspects of human life. Sustainable development refers to a process during which the people of a country meet their needs and improve their life regardless of consuming the resources which belong to next generations. A growing world population has an adverse effect on the earth's natural settlements and urban sprawl has led to irresponsible consumption of energy, the gradual warming of the planet and the increase in environmental pollution. Yet, a high amount of energy loss derives from non-standard methods of buildings for heating and cooling and inconsistency with climatic conditions. Therefore, sustainable development and applied concepts for sustainable development have been consistent with aims and intentions of modern architecture, proposed as an effective factor to achieve aims of sustainability. This research is a qualitative study conducted via descriptive-analytical method. In this research, library sources have been used to examine principles of sustainable architecture design in crowded residential complexes with an outlook to resuscitation of nature in architecture.
\end{abstract}

Keywords: sustainable architecture, nature in architecture, green roof, green residential complex

\section{INTRODUCTION}

Environmental degradation through increased energy consumption in the world, destruction of forests and meadows and species extinction occurs in case it is discussed on sustainability of environment in most of the international societies throughout the world. After the Industrial Revolution, use of natural resources around the world was made with the purpose of economic exploitation and industrial development was formed, such that the man and nature turned to the victim of the hasty movement to industrial growth. This goes with this view that it has already pursued the economic growth when it has found the economic power as sufficed, then environmental problems have been discussed and their losses will be compensated. Yet, after industrial revolution, the scholars perceived that if these events continue and the industrial growth is pursued, many materials and aims of human societies will be threatened, of which it can refer to the environment so that most of developing and developed societies face it today. This refers to an outlook which has been being proposed as one of the justifications for economic process and industrial development, yet they perceived that compensation is an imaginary discussion regarding type of exploitation from natural resources and type of pollutions appeared in the environment. These pollutions raise problems for developing and developed countries from different aspects such as Cultural and social 
problems and crises from them and the environmental problems such as global warming, the hole in the ozone layer, acid rain and so forth.

\section{THEORETICAL BACKGROUND}

\section{SUSTAINABLE ARCHITECTURE}

The use of the concepts of sustainability and goals of sustainable development to reduce energy loss and environmental pollution in architecture has raised an issue called sustainable architecture. In this architecture, the building has not just adapted itself with the climatic conditions of the region, but also has made a mutual relationship with the region, so that buildings are assumed as the birds which adapt themselves with new conditions in the environment and regulate their metabolism. The sustainable architecture which has been assumed as the subset of the sustainable design can be considered as one of the important contemporary events, accounted as a logical reaction to the problems in the industry age. For instance, $50 \%$ of fuel reserves are consumed in the buildings which this will result in environmental crises, thus the necessity to create and develop issue of sustainability in the architecture can be properly witnessed. Sustainable architecture like other issues of architecture has specific principles and rules, encompasses the stages below:

- Savings of energy

- Design to return to the life cycle

- Design for humans

Each stage above has their specific strategies (Herdeg, 2011). Recognition and study of these implications induce the architect to deeper understanding of the environment that must be designed.

Sustainable energies

Sustainable energy implies constant supply of energy to meet the needs without jeopardizing the ability of future generations to meet their needs. The technologies which contribute in sustainable energy include renewable energy resources such as hydropower, solar energy, wind energy, geothermal energy, wave energy and artificial photosynthesis as well as the technologies which have been designed to improve energy efficiency. Therefore, Twin Pillars of Sustainable Energy include energy efficiency and renewable energy. It must differentiate the term "sustainable energy" from other terms in this context such as alternative energy, because sustainable energy puts emphasis on the ability of energy source in providing energy. Sustainable energy might raise environmental pollution to a relative extent, but amount of pollution is not relatively high to prohibit large use of it as a source in an infinite time (Moradi, 2010). Sustainable energy differs from low-carbon energy, because the term "low-carbon energy" is sustainable from this perspective that it does not add carbon dioxide to the atmosphere. Green energy is another term at this area. Green energy refers to an energy that can be extracted, produced or consumed without impact on the environment. Our planet has a natural capacity to recover, thus the energy that the pollution from it does not exceed from the limit of this ability may be called green (Moradi, 2011). Green energy refers to a sub-set of the renewable energies, indicating those renewable energy resources that raise the most environmental benefits. Endless energy is called infinite energy and eternal energy. Renewable energy has been regarded as the endless energy which is infinite and eternal; the technologies used for this purpose includes energy, wind energy, wave energy, geothermal energy, tidal energy, ethanol bio fuel, hydrogen and hydroelectric power (Vahedi, 2013).

\section{GREEN ARCHITECTURE}

Green architecture has been introduced as one of the most important modern architecture styles which encompass various environmental, climatic, social and economic aims. Use of this architecture can cause 
saving of energy, creation of vitality among people and stylized space. The green architecture has various elements including green roofs, green walls, use of wind turbines, solar cells and so forth (Oveisi, 2009). Green architecture has arisen from sustainable architecture and sustainable development which this has arisen from need of the man against adverse outcomes of the industrial and consuming world at the current age. Protection from the world's natural resources, protection from pollution and other environmental pollutions, protection from ozone layer, physical and mental health, the future of humanity and so forth have been regarded as the issues proposed in this context, i.e. their necessity reveals as a global duty.

\section{THE METHOD TO USE NATURE AND GREEN ARCHITECTURE IN RESIDENTIAL COMPLEXES}

Any green building requires a creator before being created, that is, creation of a green building assists for the health of an individual who lives in it and the surrounding environment, supports him and causes satisfaction and utility for him. This requires use of the strategies confirmed in the architecture; some of these are strategies mentioned follow:

-Use of natural energy in everyday consumption

-stability of the indoor status

-Use of waste and effluent water for irrigation of green spaces

-Use of appropriate methods to reduce wasted energy and optimize energy consumption

-attention to climatic characteristics of the region

-avoidance from damage to land status for more benefit

-reaching to the highest quality of life in the light of reliance on environment

-how to use land

-attention to ecology of region

-use of non-chemical recyclable materials and the materials which do not damage to human health

-design through the materials close to the nature

-use of natural plants for inspiring the living design

\section{REDUCTION OF FUEL CONSUMPTION USING GREEN RESIDENTIAL COMPLEXES THE COLOR OF WALL IN GREEN BUILDINGS}

There is a mutual relationship between color of wall surfaces and the extent to which the solar energy is received. Using various colors at exterior surfaces of the walls in the building, it can control thermal impacts of sunlight in indoors. Light colors might reflect $85 \%$ of the solar energy, yet reflection feature of dark colors is about $15 \%$ or less (Setyowati,2013).

\section{WALL INSULATION IN GREEN BUILDINGS}

Energy due to lack of suitable thermal insulation in the building is wasted through all the surrounding surfaces of building including walls, ceilings and the floors that connect to the uncontrolled space or controlled space inside the building; thus compliance with thermal insulation in design and implementation of buildings reduces needing to heating and cooling and avoids loss of heat and cool, causing substantial saving of energy consumption (Emilsson,2007). Major types of existing insulation in Iran include Rockwool, Glass wool, Nitrile Rubber, Ceramic Wool, Polyurethane foam, Mineral Wool, Ceramic Wool, etc. in selection of thermal insulation for the walls and ceilings, the resistance of 
insulation against heath and forces, behavior against fire and water absorption must be taken into consideration.

\section{TWO-SHELLED FAÇADE FOR ENERGY OPTIMIZATION}

The words which are taken as synonyms for two-shelled façade are as follow:

Two-sheet facades, two-shelled facades, dual facades, double facades, two-walled glass facades, and ventilation façade. With regard to the definition, it can define two-shelled facades as follow: "Essentially a pair of glass "skins" separated by an air corridor. The main layer of glass is usually insulating. The air space between the layers of glass acts as insulation against temperature extremes, winds, and sound. Sunshading devices are often located between the two skins. All elements can be arranged differently into numbers of permutations and combinations of both solid and diaphanous membranes.

\section{UNDERGROUND HEAT EXCHANGER IN GREEN BUILDINGS}

To reduce energy consumption in the buildings, the amount of air exchange heat through leakage from thermal shells of buildings must be reduced to a minimum extent. In airtight buildings, a mechanical ventilation system must be inevitably used to supply fresh air required for the residents. A mechanical ventilation system not just paves the way to use an air/air heat exchanger to recycle exhaust-air energy but also paves the way for use of an underground thermal exchanger to save energy and increase yield of building in terms of energy. Yet, use of underground heat exchangers is not limited only to houses with mechanical ventilation systems, but they can also be used in buildings with air heating system. The temperature of ground depth in winter is more than the temperature of outdoor air, yet it is less than temperature of outdoor air in summer. This difference of temperature can be used to preheat the cold indoor weather in winter and precool the hot indoor weather in summer and provide heat and comfort conditions without consumption of energy. Therefore, use of underground exchangers which enter the fresh outdoor air into the building is a way to reduce energy consumption in the buildings. Underground heat exchanger is called to the air canals which are located in underground and enter the fresh air into the building after passing through it. The temperature of air passing through the underground tubes changes through energy exchange with ground and enters to the building with a temperature closer than the outdoor temperature (Bradley,2010). Length and diameter of the underground heat exchanger tubes depends on the building size in which the exchanger is used and the amount of required energy. For instance, an underground heat exchanger in a small residential building can have a diameter about $20 \mathrm{~cm}$ and a length about $40 \mathrm{~m}$. in the underground heat exchangers in small buildings, the cold outdoor air is sucked into a tube which is located at the depth of 1 meter beneath the building, whereby the temperature of cold outdoor air increases to a large extent at the coldest winter days before entering into the building. In summer, the hot outdoor air reduces to a large extent by passing through the mentioned system before entering into the building (Aben, 2012). Various factors affect amount of energy exchange between ground and the air passing through the thermal exchanger and as the result amount of energy saving. Soil type, soil density, heat capacity and heat transfer coefficient of soil, soil annual temperature difference, the distance of exchanger to adjacent buildings, groundwater levels, fluctuations in the amount of air required for ventilation and air exchange, outdoor temperature and factors relating to the underground heat exchanger such as the number of converter pipes, length of pipes, diameter of pipes, the distance between the pipes and the depth of the pipes have been mentioned as the factors which affect amount of energy exchange in this exchanger and energy saving.

\section{GREEN ROOF}

A green roof refers to a roof covered in total or part via vegetation and soil or growing medium. The term "green roof" can be considered for the roofs which consider the concepts of green architecture such as solar panels and/or photovoltaic panels.

Advantages of green roofs in residential complexes 
-provide a favorable space for the users of building due to embedding yard and patio

-the possibility to grow fruits, vegetables and flowers

- Reducing heating load ( by adding mass and thermal insulation layer ) and cooling the building ( through evaporative cooling ) -especially if it acts as a greenhouse or solar heating system

According to a research by Brad Bass (2005) from University of Toronto, the results indicated that green roofs can reduce the heat loss and energy consumption in winter to a large extent.

-reduction of heating impacts and urban climate changes

-increase of living area(green roofs can be used as the recreation and relaxation spaces)

-Reduce flooding

-Air purification and reduction in carbon dioxide in the air

- Reduce and regulate the intensity of the sounds to $\mathrm{dB} 18$ that come into the building and come out to the $\mathrm{dB} 3$ or more

- Increase the habitat of animals in residential areas

-Improve scenery around the building by providing a beautiful green space

-increase lifetime of roof membrane by protecting from it against harmful UV rays and air and water damages

\section{ROLE OF GREEN ROOF IN ENVIRONMENTAL SUSTAINABILITY OF RESIDENTIAL COMPLEXES: REDUCTION OF IMPACTS OF THERMAL ISLANDS}

Large cities due to having extensive hard and impervious surfaces devoid of vegetation absorb the heat sunshine and act as thermal energy emitting sources. Such state is called heat island. In this state, there is a substantial temperature difference between urban areas that their surfaces have been covered with asphalt and asphalt shingles. The difference of heat island effect between city and suburb in summer can be up to 10 degrees Fahrenheit (Bass, 2007). In this case, the air cooling devices increase which this causes increase in amount of energy consumption and intensification of the phenomenon of greenhouse gases that destroy ozone layer. With regard to the report by United States Environmental Protection Agency, the city air temperature can become warmer than the suburbs to $6.5 \mathrm{~cm}$ (Tabrizi, 2011). Therefore, green roof can contribute against healthy environment.

\section{CREATION OF GREEN NATURE IN RESIDENTIAL COMPLEXES AND REDUCTION OF AIR POLLUTION IN CITY}

In urban areas, trees contribute in reducing air pollutants. Nevertheless, in most of urban sites, there is little space to plant tree which this is due to a series of impervious surfaces such as streets, parking lots , roofs and so forth. Plants absorb air pollutants through their pores and separate their particles with their leaves and enable to break the specific organic compounds such as polyaromatic hydrocarbons in plant tissues or in soil (Baker \& Brooks, 2009). In addition, they indirectly reduce air pollution through reducing the surface temperature by means of cooling secretions and shade, causing decrease of photochemical reactions like ozone in the atmosphere (Bradley Rowe, 2010). Since a variety of plant species have different abilities to omit air pollutants and reduce greenhouse gases, it can select more effective species to maximize improvement of air quality. For instance, evergreen pines might have more benefits than deciduous trees, because they will enable to have a better role by maintaining annual leaves.

\section{REDUCING CARBON DIOXIDE}


The earth is warming caused by natural cycle and the burning of fossil fuels. The burning of fossil fuels releases carbon dioxide as a byproduct of combustion. Since carbon dioxide is one of the atmosphere gases that prevents the transfer of thermal energy near ground surface to higher surfaces, it increases greenhouse effect as a confounding factor and increases the temperature of the environment. Green roofs can be effective in reducing carbon dioxide in two methods below:

1-carbon has been the main component in structure of plants, decomposed naturally in plant tissues through photosynthesis and in soil bed through root exudates of plants.

2-reduction of energy through insulating building and reducing urban heath island effect (Oraki Kuhshouri, 2011).

\section{ROLE OF GREEN ROOF IN ECONOMIC SUSTAINABILITY}

Concerning economic sustainability, it must pay a particular attention to the factors which cause saving of energy. Green roof can be used to save energy and avoid loss of resources. Two factors are of great importance in influence on sun ray which radiates on the surface of ceiling of buildings, i.e. the first is surface of branches and leaves of trees and the second is type and thickness of soil. The more diversity of branches and leaves, the heat pressure through ceiling to inside will be less and ultimately the temperature of ceiling temperature will be less. The more amount of soil thickness, it will act as a better insulator and cause lack of reaching warmth to the ceiling and cooling through evaporation. Further, Keep water from rainfall is also affected by factors such as slope and depth of layers of green roof (Oraki Kuhshouri, 2011). Green roof can store water and control floods. The more thickness of green roof, more moisture can remain. These cause reducing amount of economic costs to regulate weather inside the house and reducing loss of resources.

\section{ENERGY CONSUMPTION AND GREEN ARCHITECTURE PATTERNS}

What has proposed the green architecture as a novel attitude in construction is the need of today's societies against adverse effects and industrial outcomes of the current age. Green architecture which has arisen from sustainable development refers to a phenomenon that paves the way for protection from natural resources, physical and mental health and creation of a suitable space regarding the optimal energy consumption. The world society lives beyond its facilities so that we are required continuing our life at this limited time and place through proper patterns so as not to jeopardize the ground capitals for the future generations. Design of architecture with green notion is a process to resolve the problems during which the natural resources are damaged the least; in the meantime, in addition to optimal use of resources and materials, longevity and return to nature cycle must be considered. Currently, it is the time that the resources are depleting, which this might be a concern for the architect, urban designers, urban planners, architects, engineers and experts so as to adapt the human sustainability with nature sustainability. Hence, the strategies which can be effective in the green architecture based on major factors in sustainability of development and city are as follows:

-the buildings must be designed and established in a way to provide access to public transport, Bicycle crossing path, access of the pedestrian to major services which this diminishes use of automobile.

-the buildings must be replaced in a way to exploit from the existing plants. Deciduous trees in south, east and west of building reduce the amount of cold in winter. Hedges and rows of bushes and shrubs can suppress the cold winter winds or transfer the summer cool breeze to the building.

-the building must be designed via self-sufficient energy

- Conjoined buildings minimize exterior cover costs of building

-wastes of construction materials must be reduced by design of standard height of ceilings and dimensions of building 
-the local construction materials must be used; transport is of great importance in terms of environmental pollution and energy consumption

The factors contributing in design of green building

-establishment of buildings on the site including useful paths and accesses

-orientation of buildings regarding sun and surrounding environment

-arrangement of interior rooms, windows and doors

-dimensions and aspects of buildings and the environmental components

- Color, façade, decoration of buildings and environment

\section{DESIGN OF GREEN HOUSES}

-it is better to be smaller; use a good plan of interior spaces so that the total size of building and the used resources in maintaining the building are kept as less as possible.

-design sufficient energy; use insulation at high level and windows with high capability in direction with sunlight and the sealed structure.

Free comfort, solar heat, daylight and natural cooling can be fitted with effective value in most buildings .

-grain free energy; design buildings with solar heater and electricity converter or solar facilities for future generations

-proper use of materials; reduce wastes through design for the standard height of ceilings and dimensions of building

-simplify the disposal of waste for the residents. Consider the trash bins near kitchen for the process of disposal of waste

- the systems for disposal of water in the roof can be considered to collect rain water and use of it in the irrigation

\section{Green materials}

-avoid using the chemical materials which destroy ozone in the mechanical equipment and insulators

-use of construction materials gained from the place; transport is of great importance in both energy consumption and public pollution.

-use Waste from construction materials or products obtained from materials that can return to the cycles of nature such as cellulose, plywood, brick floor carpets made of ground glass and use of recycled plastics in the form of lumber and flooring .

-search authentic wood products; use timber from controlled forests in which the trees are cut

-Avoid substances that are self-polluting gas: oil and solvent-based paints, adhesives, laminates, wood and many other materials and construction products release formaldehyde and volatile organic compounds VOC.

\section{GREEN FACILITIES}

Submit Date: 21.06.2016, Acceptance Date: 23.07.2016, DOI NO: 10.7456/1060AGSE/049

Copyright (C) The Turkish Online Journal of Design, Art and Communication 
Use of high-efficiency lighting and appliances; Fluorescent lamp is suitable from aesthetic perspective and it is cheaper than white light.

Use of water-sufficient water; Water Retention toilets, showers and bathrooms not only reduce water consumption but also reduce the load of septic system or sewer system performance. Equipment deployment reduces cost of hot water.

Executive instruction of green architecture for residential buildings- green land use to avoid energy consumption and reduce pollution

Keep constructing in developed regions; despite urban collapse, agriculture is maintained, whereby the public services and transport are provided.

-design multipurpose maps and projects in which the projects, residential and commercial uses are integrated to assist for creating living communities and reducing the largest pollution source which is used of automobile

-build the buildings in a way that access to public transport and access to major services are provided. This reduces use of automobile. Further, driving can reduce by working at home. Therefore, take this point into consideration that working at home requires telephone line.

-repair old buildings; repair of buildings is the most biological construction.

-the buildings must be built in a way to reduce their environment

-replace the buildings in a way to exploit from the existing plants

\section{REFERENCES}

Estakhri, M. 2013, the design of green roofs, urban sustainable development conference, Hamadan.

Afshari Basir , N , 2009, examination of the role of green architecture in sustainable development of the city , the National Conference of clean architectural, Yasouj .

Hedayati Koliji, F. TAHERIAN Moghaddam, Z. 2013, evaluating the use of green roofs in urban space design, the first regional conference on architecture and urbanism, Saghez, Saghez Applied Science and Higher Education Center .

Vahedi, M, mehrabi, H. Abu Torabi Zarchi , H. 2013, the integration of solar photovoltaic systems and green roofs, the National Conference on Renewable Energy and Clean, Hamedan, tomorrow environmental seminar.

Oveisi, Saman , 2009, to investigate the cognitive process in the Persian garden, landscape architecture master's thesis, University of Shahid Beheshti .

Moradi , S. , 2006 , set the environmental conditions, Shahidi Publications, Tehran .

Sheikh Asadi , F. , 2013, Iranian garden , Organic museum, First National Conference on Tourism , Geography and sustainable environment, Hamedan, - Association of Hegmataneh environment .

TAHERIAN Moghaddam, Z. , 2012 , Green Roof as an innovative approach to sustainable city , first regional conference on architecture and urbanism, Saghez, Saghez Applied Science and Higher Education Center .

Alavi, Y, 2011, optimal strategies for sustainable architecture in big cities, the National Conference on Architecture, Building and Urban Development, Isfahan .

Mo'ayyeri Nejad , H. , 2013 , green spaces and green roofs in developed cities, the International Conference of Civil Engineering, Architecture and urban development, Tabriz .

Nikbakht , A , 2004 , medicine in the perspective of modern landscaping: the healing garden, Quarterly of bagh nazar, Institute of nazar, the first, second, winter.

Tabrizi , O , 2011, green architecture as a way to green development, National Conference on sustainable architecture and urban development, Karaj . 
1. Oraki Kohshori , M. , 2011, to evaluate the environmental and economic benefits of green roofs in the city of Ahvaz, the first national conference on environmental crisis and its solutions , Kish.

Aben, Rob and de wit Saskia, (2012). "The Enclosed Garden" , (History and Development Of The Hortusconclusus and its Reintroduction into the present- day urban Landscape) second revised edition , 2001,010 publishers, Rotterdam.

Baker, A.J.M., Brooks, R.(2009). Terrestrial higher plants which hyperaccumulate metallic elements - a review of their distribution. Journal of ecology and phytochemistry. Biorecovery ,1 (2) : 81-126.

Bass, Brad. (2007). Green Roofs and Green Walls: Potential Energy Savings in the winter. Toronto : Adaptation \& Impacts Research Division Environment Canada at the University of Toronto Centre for Environment. $\bullet$ Benefits of Green Roof(n.d.). Available

Berndtsson , J.C., Bengtsson, L., Jinno, K. (2009). Runoff water quality from intensive and extensive vegetated roofs. Journal of ecological engineering, 35:369-380. Available from : www.sciencedirect.com.

Bradley Rowe, D. (2010). Green roofs as a means of pollution abatement. Journal of Environmental Pollution, 159: 2100-2110. Available from: www.sciencedirect.com.

Emilsson, T., Czerniel Berndtsson, J., Mattsson, J.E., Rolf, K., (2007). Effect of using conventional and controlled release fertilizer on nutrient runoff from various vegetated roof systems. Journal of Ecological Engineering, 29: 260- 271

Gifford, Robert, (1997). "Environmental Psychology, Principles \& Practice”, Allyne\&Bacon

Herdeg, Klaus,(2011). "Three Gardens Formal structure in Islamic Architecture Of Iran and Turkistan", preface by Oleg Grabar, Rizzoli International publications, INC United States of America.

Setyowati,Erni (2013),Green Buildings Design Concepts of Healthcare on The Orthopedic Hospital, Jurnal of Social and Behaviare Scienses,p.189-199

www.sciencedirect.com

www.greenroof.ir

www.Wikipedia.com

Daneshju.ir 